\title{
PENGENDALIAN SANITASI MAKANAN DENGAN METODE HACCP (HAZARD ANALYSIS CRITICAL CONTROL POINT) DI ASRAMA HAJI DONOHUDAN, BOYOLALI, JAWA TENGAH
}

\section{MUHAMMAD IRFAN AGUNG LAKSANA, JULI SOEMIRAT}

\author{
Program Studi Teknik Lingkungan, Fakultas Teknik Sipil dan Perencanaan \\ Institut Teknologi Nasional Bandung \\ Email: irfanagungl14@gmail.com
}

\begin{abstract}
ABSTRAK
Penyelenggaraan ibadah haji merupakan tugas negara. Pemerintah memiliki tanggung jawab dalam menjaga kondisi kesehatan jemaah, terutama keamanan pangan yang disediakan pihak katering. Penelitian ini bertujuan untuk menggunakan metode HACCP dalam pengendalian sanitasi makanan. Lokasi penelitian berada di Asrama Haji Donohudan, Boyolali, Jawa Tengah dam menggunakan data sekunder berupa indikator Coliform dan zat kimia pestisida, sianida, formalin, boraks, dan Rhodamin B. Critical Control Point (CCP) didapatkan pada 5 (lima) tahapan proses, yaitu pencucian peralatan masak dan makan, penyajian masakan, penerimaan pastel, kesehatan dan pendidikan higiene pekerja, dan penyiapan jus jambu. Dapat direkomendasikan perlunya tim HACCP yang bertanggungjawab atas sistem HACCP, tersedianya air yang memenuhi syarat kesehatan, disinfeksi peralatan masak dan makan, sertifikasi pekerja serta pendidikan higiene untuk semua manajemen dan pekerja.
\end{abstract}

Kata kunci : Asrama haji, sanitasi makanan, HACCP, Critical Control Point

\begin{abstract}
Organizing pilgrimage is a state duty. The government has the responsibility to protect their health condition, especially the food safety provided by the caterer. The purpose of this study was to apply HACCP method in food sanitation. This research was conducted in the Donohudan Hajj Boarding House, Boyolali, Central Java and using secondary data consisted of Coliform indicator bacteria, pesticides, formalin, borax, cyanide, and rhodamine B. CCP (Critical Control Point) were obtained at 5 (five) stages of the process, namely washing of cooking and eating utensils, serving foods, receiving pastels, health and hygiene education for workers, and preparing guava juice. It can be recommended that there is a need for a HACCP team responsible for the HACCP system. It is also recommended to provide a safe drinking water supply, disinfection of all cooking and eating utensils, health certification of workers, and food sanitation education for all.
\end{abstract}

Keywords: Hajj boarding house, food sanitation, HACCP, Critical Control Point 


\section{PENDAhUlUAN}

Ibadah haji merupakan tanggung jawab pemerintah, karena penyelenggaraannya merupakan tugas negara. Asrama Haji Donohudan merupakan asrama haji yang berkapasitas hingga 33.200 jemaah dan berlokasi di Kecamatan Ngemplak, Boyolali, Jawa Tengah. Selama jemaah singgah di asrama haji, PPIH (Panitia Penyelenggara Ibadah Haji) wajib menyediakan makanan yang higienis, karena makanan merupakan tempat yang sangat baik untuk pertumbuhan mikroba yang patogen. Hal tersebut bertujuan agar jemaah haji terhindar dari wabah penyakit bawaan makanan.

Higiene sanitasi adalah upaya untuk mengendalikan faktor risiko terjadinya kontaminasi terhadap makanan, baik yang berasal dari bahan makanan, orang, tempat, dan peralatan, agar aman dikonsumsi. Aplikasi sanitasi mengacu pada praktik higienis yang dirancang untuk memelihara lingkungan yang bersih dan sehat untuk produksi, pemrosesan, persiapan, dan penyimpanan makanan.

Dari uraian di atas, diperlukan suatu sistem keamanan pangan untuk menjamin terciptanya kondisi sanitasi makanan yang baik di asrama haji, yaitu HACCP (Hazard Analysis and Critical Control Point) yang melakukan pendekatan sistematis untuk manajemen keamanan pangan dan bertujuan untuk mengidentifikasi bahaya yang mungkin terjadi selama tahapan proses pangan dan menerapkan pengendalian yang akan mencegah terjadinya bahaya tersebut.

\section{BAHAN DAN METODE}

Penelitian ini menggunakan pendekatan kualitatif dengan metode deskriptif yang bertujuan untuk mengumpulkan informasi aktual secara rinci dengan menggambarkan segala fakta yang ada, mengidentifikasi masalah dan mengevaluasi informasi/data yang diperoleh. Penelitian dilakukan dengan mendapatkan data sekunder yang berasal dari Jurnal Human Media Balai Besar Teknik Kesehatan Lingkungan dan Pengendalian Penyakit Yogyakarta Volume 9 Nomor 2, Desember 2015 dengan penulis Murwani dan E. Kristanti dan data tersebut dipergunakan untuk melakukan perencanaan tindakan pengendalian. Data-data sekunder tersebut terdiri dari data mikrobiologi dan kimia..

Analisis data dilakukan dengan merencanakan 12 langkah HACCP, yaitu: (1) membentuk tim HACCP; (2) mendeskripsikan produk; (3) mengidentifikasi rencana penggunaan; (4) menentukan langkah-langkah pemrosesan; (5) mengonfirmasi diagram alir di lapangan; (6) membuat daftar semua potensi bahaya, melakukan analisis bahaya, dan membuat asumsi; (7) menentukan Critical Control Point, (8) menentukan batas kritis untuk setiap CCP; (9) menyusun sistem pemantauan untuk setiap CCP; (10) menetapkan tingkat perbaikan untuk setiap penyimpangan yang terjadi; (11) menetapkan prosedur verifikasi; dan (12) menetapkan dokumentasi dan pencatatan.

Penentuan tingkat risiko bahaya pada makanan diperoleh dari korelasi antara probability (kemungkinan terjadi bahaya) dan effect yang terdapat pada Gambar 1. Setelah didapatkan tingkatan risiko bahaya, maka dilakukan dengan menentukan CCP, dan tindakan perbaikan dari setiap CCP.

\section{PEMBAHASAN}

Data sekunder yang didapatkan terdapat pada Tabel 1 sampai Tabel 3. Data menunjukkan terdapat beberapa sampel yang teridentifikasi negatif $E$. coli, namun angka ALT nya cukup besar, sehingga perlu dilakukan pengujian ulang untuk memastikan keakuratan hasil yang 
diperoleh, akan tetapi tidak disebutkan sudah dilakukan pengujian ulang atau belum, karena piring positif $E$. coli, sedangkan gelas, sendok, panci, wajan, dan penjamah dapur 2 negatif $E$. coli, namun angka ALT nya cukup besar. Hal ini sangat berbahaya, karena peralatan makan akan langsung digunakan oleh para calon jemaah haji. Proses pencucian peralatan masak dan makan di Asrama Haji Donohudan tidak dilakukan disinfeksi, yaitu dilakukan perendaman pada suhu $80^{\circ} \mathrm{C}$ selama 2 menit setelah pencucian.

Tabel 1. Data Sekunder Agen Biologis Pada Peralatan dan Penjamah Makanan

\begin{tabular}{|c|c|c|c|}
\hline \multirow{2}{*}{ No. } & \multirow{2}{*}{ Jenis Sampel } & \multicolumn{2}{|c|}{ Hasil Pengujian } \\
\hline & & ALT (CFU/ $\left.\mathrm{cm}^{2}\right)$ & E. coli $(+) /(-)$ \\
\hline 1 & Usap piring & 2.100 & Positif \\
\hline 2 & Usap gelas & 120 & Negatif \\
\hline 3 & Usap sendok & 18.000 & Negatif \\
\hline 4 & Usap panci & 3.700 & Negatif \\
\hline 5 & Usap wajan & 150.000 & Negatif \\
\hline 6 & Usap penyaji Madinah 1 & 2.600 & Positif \\
\hline 7 & Usap penyaji Madinah 2 & 9.800 & Positif \\
\hline 8 & Usap pekerja ruang dapur 1 & 2.500 & Positif \\
\hline 9 & Usap pekerja ruang dapur 2 & 1.300 & Negatif \\
\hline \multicolumn{3}{|c|}{$\begin{array}{ll}\text { Sumber } & : \text { (Murwani dan Kristanti } \\
\text { ALT } & \text { : Angka Lempeng Total } \\
\text { E. coli } & : \text { Escherichia coli } \\
\text { CFU } & : \text { Colony Forming Units }\end{array}$} & \\
\hline
\end{tabular}

Tabel 2. Data Sekunder Agen Biologis Pada Makanan dan Minuman di Asrama Haji Donohudan

\begin{tabular}{clcc}
\hline No. & Jenis Sampel & Baku Mutu & Hasil Pengukuran* \\
\hline 1 & Makanan siap saji & O CFU E. coli/gram & $\mathbf{3 4 5}$ \\
2 & Makanan ringan & O CFU E. coli/gram & 0 \\
3 & Teh manis & O CFU E. coli/ml & 0 \\
\hline
\end{tabular}

Sumber : (Murwani dan Kristanti, 2015)

*) tidak diketahui unitnya, diasumsikan = ALT

Data terkait keberadaan bakteri E. coli pada masakan selain dari Tabel 2. tidak didapatkan, serta tidak diketahui pula pada suhu berapa masakan dibuat, sehingga diasumsikan terjadi kontaminasi silang dari peralatan masaknya.

Tabel 3. Data Sekunder Terkait Agen Kimiawi Yang Terkandung di Dalam Snack

\begin{tabular}{lccccc}
\hline \multirow{2}{*}{ Jenis Sampel } & \multicolumn{5}{c}{ Parameter } \\
\cline { 2 - 5 } & Formalin & Boraks & Rhodamin B & Pestisida & Cyanide \\
\hline Pastel & Negatif & Positif & $*$ & $*$ & $*$ \\
\hline
\end{tabular}

Sumber : (Murwani dan Kristanti, 2015)

* : : Tidak diperiksa

Bahan masakan tersebut tidak diuji $E$. coli nya 
Setelah menganalisis data sekunder, diperlukan asumsi dasar. Asumsi dasar yang dibuat karena kurang lengkapnya data sekunder yang didapatkan, sehingga dibuat berdasarkan studi literatur seperti membaca buku yang kemudian disesuaikan dengan data sekunder yang ada. Asumsi dasar terhadap potensi bahaya bagi keamanan pangan di Asrama Haji Donohudan terdapat pada Tabel 4.

Tabel 4. Asumsi Bahaya Agen Biologis

\begin{tabular}{|c|c|c|}
\hline No & Jenis Sampel & Asumsi \\
\hline 1 & $\begin{array}{l}\text { Usap piring, gelas, sendok } \\
\text { Usap panci dan wajan }\end{array}$ & $\begin{array}{c}\text { Peralatan masak dan makan dapat terkontaminasi bakteri, patogen, } \\
\text { yang berasal dari tangan penjamah ruang dapur dan penyaji } \\
\text { Madinah, karena pekerja tidak bertindak higienis dengan hasil usap } \\
\text { tangan positif } E \text {. coli, peralatan dan tempat penyimpanan tidak } \\
\text { dilakukan disinfeksi }\end{array}$ \\
\hline 2 & Usap penyaji Madinah 1 dan 2 & $\begin{array}{c}\text { Tangan penyaji terkontaminasi bakteri patogen, karena tidak mencuci } \\
\text { tangan sebelum \& setelah menyentuh objek dan setelah BAB (buang } \\
\text { air besar), kuku yang panjang, dan tidak menggunakan pelindung } \\
\text { tangan saat memegang peralatan makan. }\end{array}$ \\
\hline 3 & $\begin{array}{l}\text { Usap penjamah ruang dapur } 1 \text { dan } \\
2\end{array}$ & $\begin{array}{l}\text { Tangan pekerja di dapur terkontaminasi bakteri patogen, karena } \\
\text { tidak mencuci tangan setelah menyentuh objek \& setelah BAB } \\
\text { (buang air besar), kuku yang panjang, dan tidak menggunakan } \\
\text { pelindung tangan saat memegang peralatan makan. }\end{array}$ \\
\hline 4 & Makanan siap saji & $\begin{array}{l}\text { Pastel yang tidak diproduksi di dapur asrama haji, sehingga dapat } \\
\text { tercemar dari beberapa sumber, antara lain penjamah yang tidak } \\
\text { bertindak higienis. }\end{array}$ \\
\hline 6 & Jus jambu & $\begin{array}{c}\text { Gelas untuk tempat minum jus jambu tercemar } 120 \\
\text { CFU/cm² dan } E \text {. coli negatif. Sayangnya, tidak dilakukan } \\
\text { pengujian ulang } E \text {. coli. }\end{array}$ \\
\hline
\end{tabular}

Cara untuk menganalisis potensi bahaya terhadap keamanan pangan dapat menggunakan matriks pengukuran yang terdapat pada Gambar 1.

\begin{tabular}{|c|c|c|c|c|c|c|}
\hline \multirow{4}{*}{ Probability } & High & 4 & 4 & 5 & 6 & 7 \\
\hline & Real & 3 & 3 & 4 & 5 & 6 \\
\hline & Small & 2 & 2 & 3 & 4 & 5 \\
\hline & Very small & 1 & 1 & 2 & 3 & 4 \\
\hline & & & 1 & 2 & 3 & 4 \\
\hline & & & Limited & Moderate & Serious & $\begin{array}{c}\text { Very } \\
\text { serious }\end{array}$ \\
\hline & & & & Effect (S & erity) & \\
\hline
\end{tabular}

Gambar 1. Matriks Potensi Bahaya

Sumber : (Wallace dkk., 2018)

Probability ialah kemungkinan bahaya terjadi pada produk akhir. Arti dari setiap angka di dalam matriks, ialah:

1 = Sangat kecil

- Peluang teoritis (bahaya tidak pernah terjadi sebelumnya),

- Terdapat langkah berikutnya di dalam proses produksi yang akan menghilangkan atau mengurangi bahaya ke tingkat yang dapat diterima (misalnya pasteurisasi, fermentasi, dll), dan

- Kemungkinan tingkatan kontaminasi yang sangat terbatas.

$2=$ Kecil

- Bahaya akan terjadi sangat terbatas pada produk akhir, dan

- Tindakan pengendalian bahaya bersifat umum. 
$3=$ Menengah

- Kesalahan atau kekurangan tindakan pengendalian khusus tidak mengakibatkan adanya bahaya secara sistematis pada produk akhir, tetapi bahaya dapat muncul dalam persentase tertentu dari produk akhir dalam batch terkait.

4 = Tinggi (contohnya seperti, kontaminasi mikroba di sepanjang proses produksi)

- Kegagalan atau ketiadaan tindakan pengendalian khusus akan mengakibatkan kesalahan sistematis, ada kemungkinan besar bahwa bahaya ada di semua produk akhir dari batch terkait.

Effect merupakan tingkat keparahan bahaya yang berhubungan dengan kesehatan manusia. Arti dari setiap angka di dalam matriks, ialah:

1 = Terbatas

- Tidak ada masalah bagi konsumen terkait keamanan pangan, dan

- Bahaya tidak akan pernah mencapai konsentrasi yang berbahaya.

$2=$ Sedang

- Tidak ada cedera dan/atau gejala serius atau hanya jika terkena konsentrasi yang sangat tinggi dalam jangka waktu yang lama

- Efek sementara tapi jelas pada kesehatan (misalnya potongan kecil).

$3=$ Serius

- Efek yang jelas pada kesehatan dengan gejala jangka pendek atau jangka panjang yang jarang menyebabkan kematian (misalnya gastroenteritis),

- Bahaya memiliki efek jangka panjang; dosis maksimal tidak diketahui (misalnya dioksin, residu pestisida, mikotoksin, dll).

$4=$ Sangat serius

- Kelompok konsumen termasuk dalam kategori risiko dan bahayanya dapat mengakibatkan kematian,

- Bahaya menghasilkan gejala serius yang dapat menyebabkan kematian, dan

- Cedera permanen.

\section{Tingkat risiko}

a. Tingkat risiko 1 dan 2: Rendah

b. Tingkat risiko 3 dan 4: Sedang

c. Tingkat risiko 5, 6, dan 7: Tinggi

Penilaian skoring potensi bahaya pada pangan di Asrama Haji Donohudan terdapat pada tabel-tabel di bawah ini.

Tabel 5. Potensi Bahaya, Analisis Bahaya, dan Asumsi Skor Makanan dan Minuman

\begin{tabular}{|c|c|c|c|c|c|}
\hline Proses & $\begin{array}{c}\text { Bahaya } \\
\text { (sumber penyebab) }\end{array}$ & Probability & Effect & $\begin{array}{l}\text { Tingkat } \\
\text { Risiko }\end{array}$ & Asumsi \\
\hline \multicolumn{6}{|c|}{ Sayur Asem, Empal Gentong, dan Bubur Kacang Hijau } \\
\hline $\begin{array}{l}\text { Pencucian } \\
\text { peralatan } \\
\text { masak }\end{array}$ & 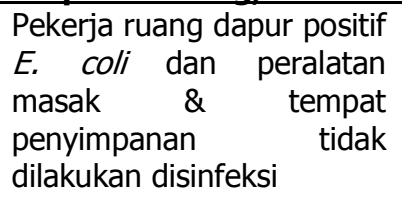 & 1 & 1 & $\begin{array}{c}1 \\
\text { Rendah }\end{array}$ & $\begin{array}{l}\text { Skor bahaya dianggap rendah, karena } \\
\text { masakan dimatangkan pada suhu } 100^{\circ} \mathrm{C} \text {, } \\
\text { sehingga kuman patogen akan mati }\end{array}$ \\
\hline $\begin{array}{l}\text { Pencucian } \\
\text { peralatan } \\
\text { makan }\end{array}$ & \begin{tabular}{lr}
\multicolumn{3}{l}{ Pekerja ruang dapur positif } \\
$E . \quad$ coli dan peralatan \\
makan \& $\quad$ tempat \\
penyimpanan & tidak \\
dilakukan disinfeksi &
\end{tabular} & & 4 & $\begin{array}{c}7 \\
\text { Tinggi }\end{array}$ & $\begin{array}{l}\text { Skor bahaya diasumsikan tinggi, karena } \\
\text { peralatan makan akan menjadi cara } \\
\text { transmisi oral langsung ada calon jemaah }\end{array}$ \\
\hline $\begin{array}{l}\text { Penyajian } \\
\text { masakan }\end{array}$ & $\begin{array}{l}\text { Piring dan penyaji } \\
\text { makanan positif } E \text {. coli }\end{array}$ & 4 & 4 & $\begin{array}{c}7 \\
\text { Tinggi }\end{array}$ & $\begin{array}{l}\text { Skor bahaya diasumsikan tinggi, karena } \\
\text { peralatan makan akan menjadi cara }\end{array}$ \\
\hline
\end{tabular}




\begin{tabular}{|c|c|c|c|c|c|}
\hline Proses & $\begin{array}{c}\text { Bahaya } \\
\text { (sumber penyebab) }\end{array}$ & Probability & Effect & $\begin{array}{l}\text { Tingkat } \\
\text { Risiko }\end{array}$ & Asumsi \\
\hline & & & & & transmisi oral langsung pada calon jemaah \\
\hline \multicolumn{6}{|l|}{ Pastel } \\
\hline $\begin{array}{l}\text { Penerimaan } \\
\text { pastel }\end{array}$ & $\begin{array}{l}\text { Pastel terdeteksi adanya } \\
\text { boraks }\end{array}$ & 4 & 4 & $\begin{array}{l}7 \\
\text { Tinggi }\end{array}$ & $\begin{array}{l}\text { Skor risiko diasumsikan tinggi karena tidak } \\
\text { dijelaskan konsentrasinya }\end{array}$ \\
\hline \multicolumn{6}{|l|}{ Jus Jambu } \\
\hline $\begin{array}{l}\text { Penyiapan } \\
\text { jus jambu }\end{array}$ & $\begin{array}{l}\text { Penyaji positif } E \text {. coli dan } \\
\text { peralatan makan \& tempat } \\
\text { penyimpanan tidak } \\
\text { dilakukan disinfeksi }\end{array}$ & 4 & 4 & $\begin{array}{l}7 \\
\text { Tinggi }\end{array}$ & $\begin{array}{l}\text { Skor risiko diasumsikan tinggi karena } \\
\text { minuman ini suhunya cukup dingin untuk } \\
\text { diminum, sehingga bila ada } E \text {. coli pada } \\
\text { gelas, maka kuman patogen tidak akan mati } \\
\text { dan langsung masuk per oral pada jemaah }\end{array}$ \\
\hline
\end{tabular}

Bahan baku di dalam proses pembuatan makanan di dapur asrama haji ini diasumsikan baik dan juga akan dimasak dengan suhu $100^{\circ} \mathrm{C}$, sehingga skor risiko akan rendah atau sangat rendah. Sekalipun berdasarkan hasil wawancara pihak BBTKLPP dengan penanggungjawab dapur Asrama Haji Donohudan, tidak dilakukan proses disinfeksi setelah peralatan masak dan makan tersebut dicuci.

Kesimpulan skoring dari uraian di atas, ialah dapat disimpulkan bahwa risiko yang tinggi terdapat saat penyajian dan saat makanan dikonsumsi oleh para calon jemaah haji. Hal ini adalah langkah pertama HACCP, yakni identifikasi risiko/bahaya serta angka bahaya. Selanjutnya akan ditentukan CCP agar bahaya dapat dikendalikan.Penentuan CCP dilakukan menggunakan pohon keputusan CCP seperti pada Gambar 2.

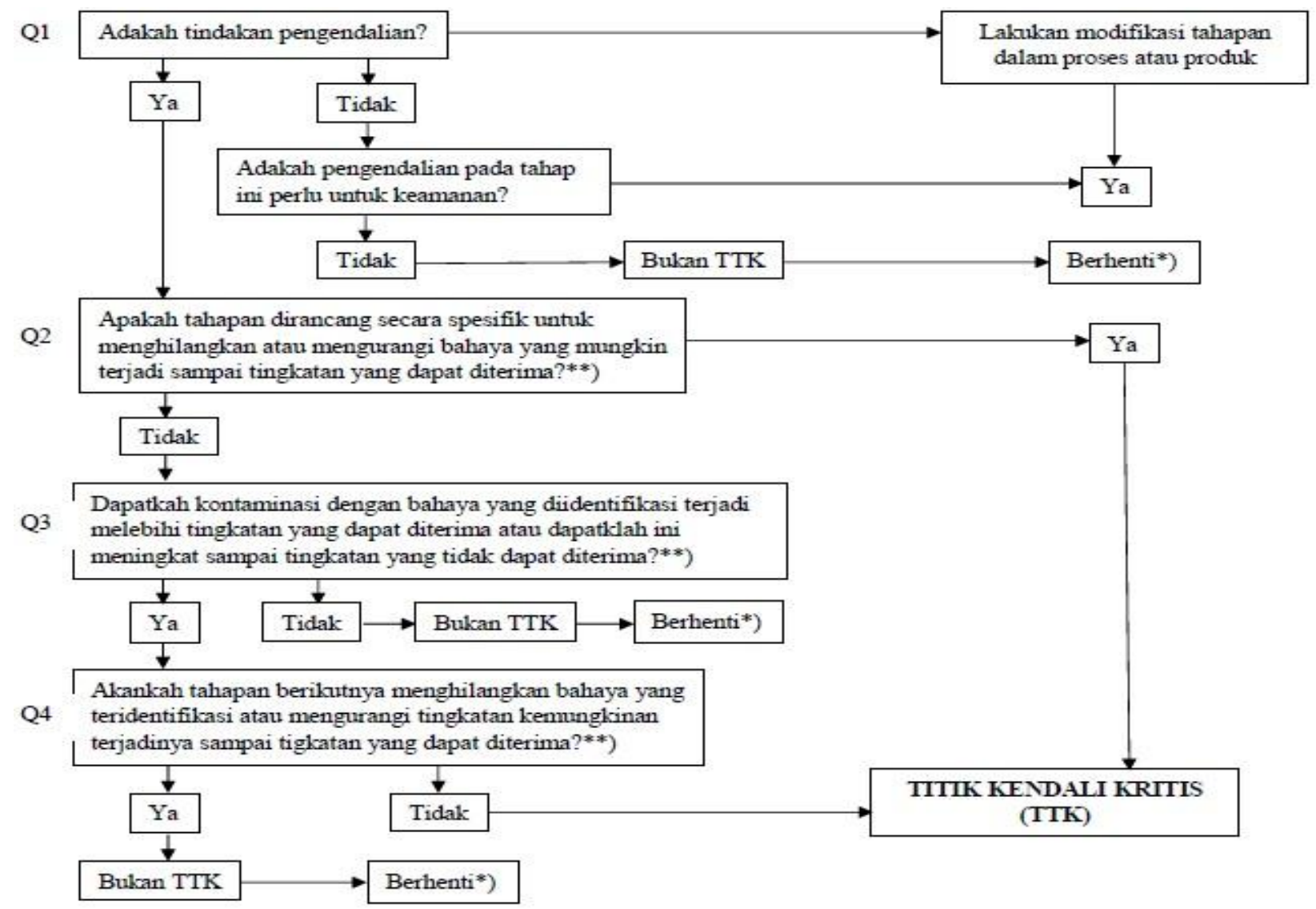

Gambar 2. Contoh Pohon Keputusan CCP (Critical Control Point) 
(Sumber: SNI 01-4852-1998)

Tabel 6. Pertanyaan dan Jawaban Pohon Keputusan CCP Pada Proses Penyajian Makanan

\begin{tabular}{|c|c|c|c|c|c|c|}
\hline $\begin{array}{c}\text { Tahapan } \\
\text { Proses }\end{array}$ & $\begin{array}{c}\text { Bahaya yang } \\
\text { Teridentifikasi }\end{array}$ & Q1. & Q2. & Q3. & Q4. & Kesimpulan \\
\hline \multicolumn{7}{|c|}{ Sayur Asem, Empal Gentong, dan Bubur Kacang Hijau } \\
\hline $\begin{array}{l}\text { Pencucian } \\
\text { peralatan } \\
\text { masak }\end{array}$ & $\begin{array}{l}\text { Pekerja ruang } \\
\text { dapur positif } E \text {. } \\
\text { coli dan peralatan } \\
\text { masak terrcemar } \\
\text { bakteri patogen }\end{array}$ & $\begin{array}{l}\text { Ya, pengecekan } \\
\text { terhadap } \\
\text { temperatur } \\
\text { pemasakan }\end{array}$ & $\begin{array}{l}\text { Ya, pemasakan } \\
\text { makanan } \\
\text { menggunakan } \\
\text { temperatur di atas } \\
100^{\circ} \mathrm{C}\end{array}$ & - & - & CCP \\
\hline \multicolumn{7}{|c|}{ Sayur Asem, Empal Gentong, dan Bubur Kacang Hijau (Lanjutan) } \\
\hline $\begin{array}{l}\text { Pencucian } \\
\text { peralatan } \\
\text { makan }\end{array}$ & $\begin{array}{l}\text { Salah satu sampel } \\
\text { usap tangan } \\
\text { penyaji positif } E \\
\text { coli dan peralatan } \\
\text { makan terrcemar } \\
\text { bakteri patogen }\end{array}$ & $\begin{array}{lr}\text { Ya, penjamah perlu } \\
\text { dilatih tentang } \\
\text { higiene personel } \\
\text { yang baik, serta } \\
\text { peralatan makan } \\
\begin{array}{l}\text { didisinfeksi } \\
\text { dicuci }\end{array}\end{array}$ & $\begin{array}{l}\text { Ya, sebelum dan } \\
\text { setelah bekerja harus } \\
\text { mencuci tangan dan } \\
\text { peralatan harus dicuci, } \\
\text { dikeringkan, } \\
\text { didisinfeksi, dan } \\
\text { disimpan di tempat } \\
\text { yang higienis }\end{array}$ & - & - & CCP \\
\hline $\begin{array}{l}\text { Penyajian } \\
\text { masakan }\end{array}$ & $\begin{array}{l}\text { Piring dan penyaji } \\
\text { makanan positif } E \text {. } \\
\text { coli }\end{array}$ & $\begin{array}{lr}\text { Ya, } & \text { dengan } \\
\text { melakukan } & \text { uji } \\
\text { kesehatan } & \text { periodik } \\
\text { pekerja ran } & \text { dan } \\
\text { mengukur suhu } \\
\text { saat disinfeksi }\end{array}$ & $\begin{array}{l}\text { Pemeriksaan } \text { periodik } \\
\text { pekerja } \\
\text { Pendidikan perilaku } \\
\text { higienis } \\
\text { Disinfeksi peralatan } \\
\text { masak dan makan }\end{array}$ & - & - & CCP \\
\hline \multicolumn{7}{|l|}{ Pastel } \\
\hline $\begin{array}{l}\text { Penerimaan } \\
\text { pastel }\end{array}$ & $\begin{array}{l}\text { Pastel terdeteksi } \\
\text { adanya boraks }\end{array}$ & $\begin{array}{lr}\text { Ya, } & \text { menguji } \\
\text { keberadaan } & \text { BTP } \\
\text { yang } & \text { tidak } \\
\text { diperbolehkan } & \end{array}$ & $\begin{array}{l}\text { Ya, melakukan survey } \\
\text { sebelum melakukan } \\
\text { pemesanan makanan } \\
\text { jadi }\end{array}$ & - & - & CCP \\
\hline \multicolumn{7}{|l|}{ Jus Jambu } \\
\hline $\begin{array}{l}\text { Penyiapan } \\
\text { jus jambu }\end{array}$ & $\begin{array}{l}\text { Peralatan makan } \\
\text { minum positif } E \text {. } \\
\text { coli }\end{array}$ & $\begin{array}{l}\text { Uji kesehatan } \\
\text { periodik pekerja } \\
\text { Suhu disinfeksi } \\
\text { peralatan makan }\end{array}$ & $\begin{array}{l}\text { Ya, pekerja } \\
\text { bersertifikat sehat }\end{array}$ & - & - & CCP \\
\hline $\begin{array}{l}\text { Q1 = Ques } \\
\mathrm{Q} 2=\text { Ques } \\
\mathrm{CCP}=\text { Criti }\end{array}$ & $\begin{array}{l}\text { Pohon Keputusar } \\
2 \text { Pohon Keputusar } \\
\text { Ontrol Point }\end{array}$ & $\begin{array}{ll}\text { CCP; } & \text { Q3 = Questi } \\
\text { CCP; } & \text { Q4 = Questic }\end{array}$ & $\begin{array}{l}73 \text { Pohon Keputusan C } \\
74 \text { Pohon Keputusan C }\end{array}$ & & & \\
\hline
\end{tabular}

Tabel 7. Penentuan Batas Kritis Dari Setiap CCP

\begin{tabular}{|c|c|c|c|}
\hline Tahapan Proses & $\begin{array}{c}\text { Deskripsi Bahaya } \\
\end{array}$ & Batas Kritis & Standar \\
\hline \multicolumn{4}{|c|}{ Sayur Asem, Empal Gentong, dan Bubur Kacang Hijau } \\
\hline $\begin{array}{l}\text { Pencucian } \\
\text { peralatan masak }\end{array}$ & $\begin{array}{l}\text { Pekerja ruang dapur positif } E \text {. coli dan peralatan } \\
\text { masak terrcemar bakteri patogen }\end{array}$ & & \\
\hline $\begin{array}{l}\text { Pencucian } \\
\text { peralatan makan }\end{array}$ & $\begin{array}{l}\text { Salah satu sampel usap tangan penyaji positif } E \text {. } \\
\text { coli dan peralatan makan terrcemar bakteri } \\
\text { patogen }\end{array}$ & $\begin{array}{l}\text { ALT bakteri }= \\
0 \mathrm{CFU} / \mathrm{cm}^{2} \\
\text { E. coli }=0 / \mathrm{gr}\end{array}$ & $\begin{array}{l}\text { PERMENKES No. } \\
1096 \text { Tahun } 2011\end{array}$ \\
\hline $\begin{array}{l}\text { Penyajian } \\
\text { masakan }\end{array}$ & Piring dan penyaji makanan positif $E$. coli & & \\
\hline \multicolumn{4}{|l|}{ Pastel } \\
\hline $\begin{array}{l}\text { Penerimaan } \\
\text { pastel }\end{array}$ & Terdeteksi keberadaan boraks pada pastel & $\begin{array}{l}\text { Cemaran kimia } \\
=\text { Negatif }\end{array}$ & $\begin{array}{l}\text { PERMENKES No. } \\
1096 \text { Tahun } 2011\end{array}$ \\
\hline
\end{tabular}

Jus Jambu 
Penentuan batas kritis diperoleh dari standar atau regulasi yang terkait. Batas kritis ini sangat penting di dalam sistem HACCP, karena potensi terjadinya pencemaran terhadap pangan diketahui. Setelah batas kritis untuk setiap CCP diketahui, catatan didokumentasikan untuk menjadi bahan pengendalian terhadap proses produksi.

Sistem pemantauan yang perlu disusun merupakan Prinsip Keempat dari sistem HACCP. Pemantauan/monitoring batas kritis harus berbasis ilmiah yang menggunakan data eksperimental, standar industri, regulasi, dan pengalaman sebelumnya, serta menggunakan peralatan yang selalu dikalibrasi secara rutin seperti alat timbang, alat pengukuran, dll., sehingga didapatkan data pengamatan yang dapat dipertanggungjawabkan. Prosedur pemantauan untuk setiap CCP terdapat pada Tabel 8.

Tabel 8. Prosedur Pemantauan Untuk Setiap CCP

\begin{tabular}{|c|c|c|c|c|c|}
\hline \multirow{2}{*}{$\begin{array}{l}\text { Tahapan } \\
\text { Proses }\end{array}$} & \multicolumn{5}{|c|}{ Prosedur Pemantauan } \\
\hline & Apa & Bagaimana & Di mana & Kapan & Siapa \\
\hline \multicolumn{6}{|c|}{ Sayur Asem, Empal Gentong, dan Bubur Kacang Hijau } \\
\hline $\begin{array}{l}\text { Pencucian } \\
\text { peralatan } \\
\text { masak }\end{array}$ & $\begin{array}{l}\text { Peralatan } \\
\text { masak }\end{array}$ & $\begin{array}{l}\text { Pemantauan secara langsung } \\
\text { ketika proses pencucian, } \\
\text { pengeringan, dan disinfeksi, } \\
\text { serta cara memasak makanan }\end{array}$ & $\begin{array}{l}\text { Tempat } \\
\text { pencucian } \\
\text { dan dapur }\end{array}$ & $\begin{array}{l}\text { Sebelum dan setelah } \\
\text { peralatan } \\
\text { digunakan, serta } \\
\text { saat pemasakan } \\
\text { berlangsung }\end{array}$ & $\begin{array}{l}\text { Kepala divisi } \\
\text { produksi }\end{array}$ \\
\hline $\begin{array}{l}\text { Pencucian } \\
\text { peralatan } \\
\text { makan }\end{array}$ & $\begin{array}{l}\text { Peralatan } \\
\text { makan }\end{array}$ & $\begin{array}{l}\text { Pemantauan secara langsung } \\
\text { ketika proses pencucian, } \\
\text { pengeringan, dan disinfeksi }\end{array}$ & $\begin{array}{l}\text { Tempat } \\
\text { pencucian }\end{array}$ & $\begin{array}{l}\text { Sebelum dan setelah } \\
\text { peralatan digunakan }\end{array}$ & $\begin{array}{l}\text { Kepala divisi } \\
\text { produksi }\end{array}$ \\
\hline $\begin{array}{l}\text { Penyajian } \\
\text { masakan }\end{array}$ & $\begin{array}{l}\text { Peralatan } \\
\text { makan }\end{array}$ & $\begin{array}{l}\text { Menguji kesehatan periodik } \\
\text { pekerja dan mengukur suhu } \\
\text { saat disinfeksi }\end{array}$ & Dapur & $\begin{array}{l}\text { Sebelum dan setelah } \\
\text { peralatan digunakan }\end{array}$ & $\begin{array}{l}\text { Kepala divisi } \\
\text { produksi }\end{array}$ \\
\hline \multicolumn{6}{|l|}{ Pastel } \\
\hline $\begin{array}{l}\text { Penerimaan } \\
\text { pastel }\end{array}$ & $\begin{array}{l}\text { Makanan } \\
\text { pastel }\end{array}$ & $\begin{array}{l}\text { Menguji kandungan boraks di } \\
\text { dalam pastel }\end{array}$ & Laboratorium & $\begin{array}{l}\text { Saat pastel diterima } \\
\text { dari pemasok }\end{array}$ & $\begin{array}{l}\text { Bagian } \\
\text { laboratorium }\end{array}$ \\
\hline \multicolumn{6}{|l|}{$\frac{\text { Jus }}{\text { Jambu }}$} \\
\hline $\begin{array}{l}\text { Penyiapan } \\
\text { jus jambu }\end{array}$ & $\begin{array}{l}\text { Penyiapan } \\
\text { jus jambu }\end{array}$ & Penyiapan jus jambu & $\begin{array}{l}\text { Penyiapan } \\
\text { jus jambu }\end{array}$ & Penyiapan jus jambu & $\begin{array}{l}\text { Penyiapan } \\
\text { jus jambu }\end{array}$ \\
\hline
\end{tabular}

Tabel 9. Prosedur Pemantauan Untuk Setiap CCP

\begin{tabular}{|c|c|}
\hline Tahapan Proses & Tindakan Perbaikan \\
\hline \multicolumn{2}{|c|}{ Sayur Asem, Empal Gentong, dan Bubur Kacang Hijau } \\
\hline $\begin{array}{l}\text { Pencucian peralatan } \\
\text { masak }\end{array}$ & $\begin{array}{l}\text { Setiap peralatan masak dilakukan pencucian dengan sabun, dikeringkan dengan lap } \\
\text { higienis, dan didisinfeksi, serta pemasakan makanan pada suhu di atas } 100^{\circ} \mathrm{C}\end{array}$ \\
\hline $\begin{array}{l}\text { Pencucian } \\
\text { makan }\end{array}$ & $\begin{array}{l}\text { Setiap peralatan masak dilakukan pencucian dengan sabun, dikeringkan dengan lap } \\
\text { higienis, dan didisinfeksi }\end{array}$ \\
\hline Penyajian masakan & $\begin{array}{l}\text { Setiap peralatan makan dilakukan pencucian dengan sabun dan didisinfeksi, serta } \\
\text { personel higiene ditingkatkan lagi }\end{array}$ \\
\hline \multicolumn{2}{|l|}{ Pastel } \\
\hline $\begin{array}{l}\text { Penerimaan pastel } \\
\text { mengandung boraks }\end{array}$ & $\begin{array}{l}\text { Pemilihan pemasok yang sudah terpercaya dan dapat dilihat proses pembuatan nya } \\
\text { secara langsung }\end{array}$ \\
\hline
\end{tabular}

\section{Jus Jambu}

Penyimpanan jus jambu Setiap peralatan makan dilakukan pencucian dengan sabun dan didisinfeksi, serta personel higiene ditingkatkan lagi

Tindakan perbaikan dilakukan setelah prosedur pemantauan. Tindakan yang terdapat pada

Tabel 9. ini perlu dilakukan jika pemantauan menunjukkan adanya penyimpangan dari batas 
kritis yang ditentukan. Tindakan perbaikan yang perlu dilakukan pihak katering/PPIH Asrama Haji Donohudan dalam menjaga kualitas makanan dan minuman yang diproduksi perlu dilakukan dari seluruh proses memasak, terutama proses-proses yang termasuk CCP. Tindakan perbaikan tidak akan sulit jika seluruh komponen di dapur dilibatkan dengan cara pelatihan dan dilakukan briefing setiap akan dilakukannya aktivitas di dapur.

\section{KESIMPULAN}

Beberapa kesimpulan penting yang bisa diungkapkan pada penelitian ini adalah sebagai berikut :

1. Pencucian peralatan masak memiliki tingkat risiko bahaya rendah, sedangkan pencucian peralatan makan, penyajian masakan, dan penerimaan pastel mempunyai tingkat risiko bahaya yang tinggi

2. Terdapat 5 (lima) proses yang merupakan CCP (Critical Control Point), yaitu pencucian peralatan masak, pencucian peralatan makan, penerimaan pastel, kesehatan dan pendidikan higiene pekerja, dan penyiapan masakan jadi.

3. Tindakan perbaikan yang diperlukan ialah setiap peralatan masak dan makan dilakukan pencucian dengan sabun dan didisinfeksi, serta sertifikasi kesehatan dan pendidikan higiene pekerja perlu ditingkatkan lagi, serta pemilihan pemasok untuk makanan yang tidak diproduksi di dapur Asrama Haji Donohudan yang sudah terpercaya dan dapat dilihat proses pembuatan nya secara langsung.

\section{DAFTAR RUJUKAN}

Awasthi, M. K., Zhao, J., Soundari, P. G., Kumar, S., Chen, H., Awasthi, S. K., Duan, Y., Liu, T., Pandey, A., dan Zhang, Z. (2019). Sustainable Management of Solid Waste Sustainable Resource Recovery and Zero Waste Approaches (pp. 79-99): Elsevier BPOM. (2004). Food Watch: Sistem Keamanan Pangan Terpadu (Bahan Tambahan Ilegal Boraks, Formalin, dan Rhodamin B).

Codex. (2009b). Hazard Analysis and Critical Control Point (HACCP) System and Guidelines for its Application, in Food Hygiene Basic Texts, 3rd edn. Joint FAO/WHO Food Standards Programme, Food and Agriculture Organization of the United Nations.

Hartono, A. (2006). Penyakit Bawaan Makanan: Fokus Pendidikan Kesehatan. Jakarta: EGC.

Keputusan Kepala Badan Pengawas Obat dan Makanan Nomor HK. 00.05.5.1639 Tahun

2003 Tentang Pedoman Cara Produksi Pangan yang Baik untuk Industri Rumah Tangga (CPPB-IRT).

Marriott, N. G., dan Gravani, R. B. (2006). Principles of Food Sanitation. USA: Springer.

Mortimore, S. E., dan Wallace, C. A. (2015). HACCP: a Food Industry Briefing. United States: Wiley Blackwell.

Murwani dan Kristanti, E. (2015). Kualitas Sanitasi Makanan di Asrama Haji Donohudan, Boyolali, Propinsi Jawa Tengah, Tahun 2014. Jurnal Human Media BBTKLPP Yogyakarta, $9(2)$. 
Pal, M., Gebregabiher, W., dan Singh, R. K. (2016). The Role of Hazard Analysis Critical Control Point in Food Safety. Beverage \& Food World, 43(4), 34.

Peraturan Menteri Kesehatan Republik Indonesia Nomor 1096 Tahun 2011 Tentang Higiene Sanitasi Jasaboga

Peraturan Pemerintah Republik Indonesia Nomor 86 Tahun 2019 Tentang Keamanan Pangan.

SNI 01-4852-1998 Tentang Sistem Analisa dan Pengendalian Titik Kritis (HACCP) Serta Pedoman Penerapannya.

Soemirat, Juli. (2014). Kesehatan Lingkungan. Yogyakarta: UGM Press.

Tobing, B. (2015). Rantai Pasok Pangan (Food Supply Chain).

Undang-Undang Republik Indonesia Nomor 13 Tahun 2008 Tentang Penyelenggaraan Ibadah Haji

Wallace, C. A., Sperber, W. H., dan Mortimore, S. E. (2018). Food Safety for the 21st Century: Managing HACCP and Food Safety Throughout the Global Supply Chain, 2nd Edition. United States: Wiley. 